\title{
Does geopolitical risk and financial development matter for economic growth in MENA countries?
}

\author{
Hassen Soltani \\ Department of Administration, College of Science and Arts in \\ Balgarn, University of Bisha, \\ P. O. Box 199, Bisha, 61922, Saudi Arabia \\ bsoltani@ub.edu.sa
}

\section{Mohamed Bilel Triki*}

Department of Administration, Community College,

University of Bisha, P.O. Box 551, Bisha 61922, Saudi Arabia

And GEF2A Lab, University of Tunis, Tunisia

mtriki@ub.edu.sa

ORCID 0000-0002-0696-392X

*Corresponding author

\section{Mohamed Ghandri}

Department of Administration, College of Science and Arts in

Balgarn, University of Bisha,

P. O. Box 199, Bisha, 61922, Saudi Arabia

mghandri@ub.edu.sa

\section{Fouzi Tahar Abderzag}

Department of Administration, Faculty of Business,

University of Bisha,

P.O. Box 551, Bisha, 61922, Saudi Arabia

fabdelrzag@ub.edu.sa

Abstract. This study seeks to study the impact of financial development, foreign direct investment (FDI) and geopolitical tensions on economic growth for MENA countries. Geopolitical tensions are explored by the geopolitical variable risk index developed by Caldara and Iacoviello in 2016. We apply the Panel Vector Auto-regression (PVAR) model to a panel of MENA countries, the estimates show that the financial development factor has no impact on some countries but has an effect on others. This insignificant impact of financial development on economic growth is mainly linked to the quality of the financial

Received: March, 2020 1st Revision: February, 2021

Accepted: March, 2021

DOI:

$10.14254 / 2071$ $8330.2021 / 14-1 / 7$ systems in the MENA countries, which has remained underdeveloped, despite the improvement attempts that had been made by these countries. On the other hand, higher GPR results in higher economic vulnerability in the MENA countries, so the militaristic policies of countries and the influence of wars in 
the region brakes the development of specific economies and does not manage to fascinate foreign investors and convey economic growth.

Keywords: FDI, GPR, financial development, economic growth, MENA countries, PVAR.

JEL Classification: F23, C22, F43, C52.

\section{INTRODUCTION}

It is widely accepted today that financial development has a positive effect on economic growth. Generally, this positive influence is transmitted through two channels: the increase of investment (accumulation of capital) and the productivity factors. Empirical literature has shed much light on the productivity channel of capital accumulation. Thus, for financial development to be able to positively influence economic growth, a country must facilitate investments in technological innovations and apply methods that would reduce production costs, increase productivity, and accelerate growth.

However, the timidity of FDI, especially in developing countries, has allowed some authors to integrate financial development as a factor of attractiveness. Some authors called for a favourable institutional framework to examine the functioning of the entire financial system that allows the control of corruption, the fight against bureaucracy, the safety of depositors, the respect of the rights of shareholders as well as creditors, and the rigorous application of established contracts.

Yilmaz Bayar and Marius Dan Gavriletea (2018) and Hermes, N. and Lensink, R. (2003), have shown that the development of the financial system plays an important role for improving FDI flows. In addition, good financial system performance, which eliminates market frictions, contributes positively to the process of technological diffusion. On the other hand, Mohammad A.A and Mahmoud K.A (2014), Okon et al. (2012), Azman-Saini, Siong and AbdHalim (2010), and Kholdy, S. and Sohrabian, A. (2005) have presented that, with different econometric studies and samples, FDI flows do not allow, in the long term, technological diffusion only if a minimum level of development of the domestic financial sector is ensured.

At the beginning of the 1990s, several studies addressed the research axis of the determinants of growth rates (Barro, 1991; Okon and al. 2012). These studies show that macroeconomic variables, trade openness, financial development, regional characteristics and politics influence the rate of economic growth. In the course of this study, we seek to demonstrate that geopolitical tensions are one of the most deterministic factors of economic growth.

According to the ECB and IMF (2017), geopolitical instabilities and geopolitical uncertainties are factors influencing economic growth in an important way. In the economic literature, more research addresses the axis of the effects of geopolitical tensions, terrorist incidents, revolutions, the effect of wars on economic growth (Alesina et al., 1996; ; Sala-I-Martin, 1997; Triki and Ben Maatoug, 2020). Our aim is also to analyze the effect of geopolitical tensions on economic growth.

In this study, we aim at estimating the relationship between foreign direct investment (FDI), financial development and economic growth of MENA countries in the presence of geopolitical tensions and mentions of military-related tensions by presenting the recent index of Geopolitical Risk calculated by Caldara (2018). We explore these relationships using a panel of MENA countries with monthly frequencies covering the period 1995 through 2020. 


\section{LITERATURE REVIEW}

More recently, Mohammad A.A and al. (2014), Okon and al. (2012), Azman-Saini. S and AbdHalim (2010) have proven the role of the financial market in the effect of FDI on economic growth. Using data from 91 countries during the period (1975-2005), they adopted the approach of threshold effects to capture the dynamics of the relationship among foreign direct investment, economic growth, and the development of financial markets. This idea highlights the necessity for governments to focus on policies that aim to attract foreign direct investment flows.

Likewise, Villegas-Sanchez (2008), studied the effect of the location of Mexican firms on FDI. Indeed, it has shown that companies located in financially developed regions benefit from an increase in the productivity of FDI. Similarly, Alvaro, Chanda, Kalemli-Ozacan, and Sayek (2004), using a panel of 71 countries covering the period (1973-1995), found that foreign investment plays an ambiguous role in contributing to economic growth. Nevertheless, countries with more developed financial markets reap more benefits from foreign investment.

\subsection{The relationship between foreign direct investment and financial development}

Several studies (e.g. Islam, 1995; Osei et al. 2020; Fauzel, Sheereen. 2016; Desbordes, Rodolphe, and Shang-Jin Wei. 2014; Sahin, Serkan, and IlhanEge. 2015) pointed out that FDI has a positive and significant impact on growth in both developed and developing countries. Mahmoodi, M, and E. Mahmoodi. (2016) Mohammad A.A. and Mahmoud K.A (2014) have shown that economic growth is influenced by FDI positively in host countries. Osei et al. (2020) re-examine, for a panel of 62 countries, the relationship between financial development, foreign direct investment and economic growth using non-linear models.

\subsection{The link between financial development and economic growth}

Examining the relationship between financial development and economic growth requires an accurate assessment of financial development. Ideally, there should be a set of indicators covering the points described in section 2.1. However, indicators relating to the capacity of a financial system to allocate credits, extract and use information and exercise governance are difficult to define, and even more difficult to quantify (Beck et al., 2008).

By revisiting the relationship between financial development and economic growth in the literature, we cite a few studies: Benedictow et al. (2020) incorporated a financial accelerator mechanism operating through investments in the Norwegian economy. The results suggest that the introduction of a financial accelerator significantly strengthens and prolongs economic cycles in the forecast, especially in the face of a severe shock.

Freytag and Fricke (2017) consider that the structure of the financial sector is likely to matter, and a financial system with commercial banks that enjoy wide geographic coverage and are able to provide credit to small and medium-sized enterprises may have a greater impact on economic growth than a system concentrated in urban centers.

Durusu-Ciftci, D, Ispir, M. S \&Yetkiner, H. 2017; Braun and Raddatz (2007); Ranciere et al (2007), Jung (1986), Roubini and Sala-I-Martin (1992) and King and Levine (1993) use financial development as an effective determinant of economic growth. In the same perspective, Ang (2008), shows that Malaysia's highly developed financial system contributes to rapid economic growth. 


\subsection{The link between geopolitical tensions and economic growth}

In this section, we analyze the relationship between the GPR index and the growth rate. Several studies have addressed this line of research and seek to answer the questions: what is the effect of terrorist acts, the effects of wars, revolutions, coups d'état and governmental instability on the economic growth? To begin, Alesina and. Al. (1996) show that political instability lowers economic growth for 113 countries. Gaibulloe \& Sandler (2008) show that the internal and transnational terrorism affect negatively the economic growth in a panel of 18 European countries

Soybilgen et al. (2019) study the close link between geopolitical risks and the variable of interest the economics growth for a panel of 18 emerging countries for a period covering 1986-2016. They used the GPR index from Caldara and Iacoviello (2018). Their results show that the overall impact of disasters in economic and human development terms requires assessing the post-event situation of all institutional, social and economic sectors of activity regularly measured by all countries. Quantitative assessment of the impact of disasters must also be based on evidence in order to meet the normal reliability requirements of the national or international organization (s) that will finance recovery and reconstruction.

Ichrakieh and Zeaiter (2019), analyze the extent of geopolitical risk (GPR) on the financial stability of Turkey. They use Threshold Vector Auto Regression method (Threshold VAR) to assess the effect of GPR stemming from Saudi Arabia (regional) and Russia (global) on financial stress in Turkey. It should nevertheless be stressed that the devastating effects of many phenomena of geopolitical tensions will probably be localized and will have a significant negative impact on the macroeconomic situation of the country. However, whatever their magnitude, all disasters are likely to require interventions aimed at mitigating their dramatic impact on individuals or households. They can also have negative consequences on certain socio-economic sectors.

Triki and Ben Maatoug (2020) study the relationship between the US stock market and the price of gold in the presence of geopolitical tensions. En procédant à l'analyse du ce lien, les auteurs se sont intéressés à la structure du marché financier et marché de l'or. More specifically, they wondered if there was a split between geopolitical tensions and the financial system depending on the level of financial development developed. Their contribution is to prove that the S \& P500 is more correlated with gold during times of high geopolitical stress.

\section{METHODOLOGY}

The main objective of this study is to study the relationship between financial, foreign direct investment and economic growth in MENA countries in presence of geopolitical tensions. The methodology that is adopted in this study is the PVAR model. The choice of the PVAR model is justified by the fact that it provides two major tools of analysis. First, by relying on the dynamics of the model, the Impulse Response Functions (IRF) analysis, it is possible to detect the impact on FDI and the growth of a financial development shock. Second, the decomposition of the variance will measure the magnitude of the impact of financial development on FDI and growth.

This study explores a sample of 15 MENA countries. The data for this study is obtained from the World Bank database during the period 1995 until 2020.

\subsection{Specification of the model}

By using the PVAR methodology, the heterogeneity of the individuals will be taken into account through the unobservable individual effects $\mu$ i. These affect the growth dynamics of the countries in the 
region, while the temporal effects are introduced by time dummies variables $\mathrm{dt}$, intended to measure shocks that have affected all MENA countries uniformly at time $t$.

To verify the individual and temporal specific effects as well as to address the endogeneity problem of the variables, the mean differentiation procedure of Helmert's future observations (see Arellano and Bover, 1995) has been used. We use the first difference in order to eliminate individual effects and to instrument lagged exogenous variables. The VAR model is written as follows:

$\mathrm{Yi}, \mathrm{t}=\alpha 0+\alpha 1 \mathrm{Yi}, \mathrm{t}-1+\mu \mathrm{i}+\mathrm{dt}+\xi_{\mathrm{it}}$

Where Yi,t, composit of: GDP, FDI, indxDF, INF, GPR and OPNS.

\subsection{Abbreviations and acronyms}

GDPi,t: Growth rate of real GDP per capita.

FDI: Inflows of foreign direct investment as a proportion of GDP.

IndxDF: Financial Development Index.

INF: Inflation rate.

OPNS: Opening rate measured by the total of $\mathrm{X}^{\circ}$ and $\mathrm{M}^{\circ}$ relative to GDP.

GPR: geopolitical risk index

\section{EMPIRICAL RESULTS AND DISCUSSION}

Before studying the financial development shock on FDI and economic growth, the stationarity of the variables must be checked. Before that it is interesting to see an apercu of the evolution of geopolitical tensions.

\subsection{Historical of geopolitical tensions}

Our geopolitical risk index is developed from the work of Dario Caldara and Matteo Iacoviello. This index is calculated from the number of articles mentioning political risk in major national and international media as a percentage of the total number of articles. This statistic is updated every month. Caldara and Iacoviello (2018) construct a monthly geopolitical risk index (GPR index). This index is constructed by calculating the words indicated in articles grouping together words directly associated with: geopolitical risk, military tensions, threats of war, terrorist threats and real negative geopolitical events. As shown in Figure 1, geopolitical risk index is characterized by an oscillation with peaks being associated with various events in the majority of MENA countries.

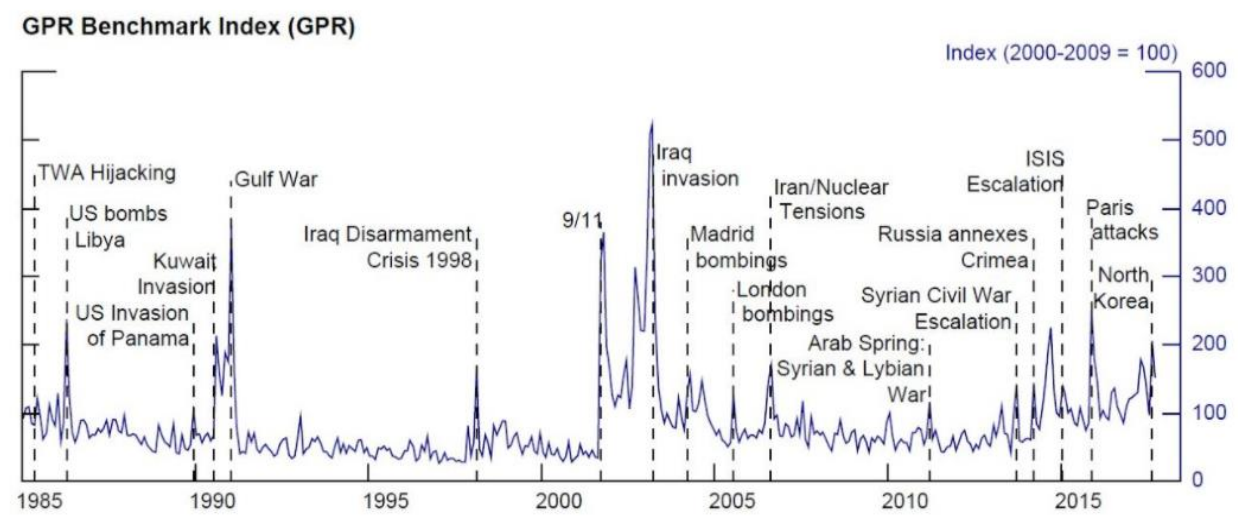

Figure 1. Geo-political Risk Index 


\subsection{Unit root test}

To show the unit root tests, the author referred to Hurlin and Mignon (2006) and Chin-Chiang, Lee and Chun-Ping, Chang (2009). In the table below, the different tests use dare shown.

Table 1

Unit root test in level

\begin{tabular}{|c|c|c|c|c|c|c|c|c|}
\hline \multirow{2}{*}{ Variables } & \multicolumn{4}{|c|}{ LLC $(2002)$} & \multicolumn{4}{c|}{ IPS (2003) } \\
\cline { 2 - 9 } & model without trend & \multicolumn{2}{|c|}{ Model with trend } & \multicolumn{2}{|c|}{ Model without trend } & \multicolumn{2}{c|}{ Model with trend } \\
\cline { 2 - 9 } & Statistic & P-values & Statistic & P-values & Statistic & P-values & Statistic & P-values \\
\hline GDP & -7.84649 & $(0.0000)^{* * *}$ & -8.43462 & $(0.0000)^{* * *}$ & -6.97634 & $(0.0000)^{* * *}$ & -5.57873 & $(0.0000)^{* * *}$ \\
\hline indxDF & -6.58374 & $(0.0000)^{* * *}$ & -5.82716 & $(0.0000)^{* * *}$ & -5.61541 & $(0.0000)^{* * *}$ & -4.10855 & $(0.0000)^{* * *}$ \\
\hline FDI & -3.22073 & $(0.0006)^{* * *}$ & -1.60194 & $(0.0546)^{* * *}$ & -2.66516 & $(0.0038)^{* * *}$ & -1.24219 & $(0.1071)$ \\
\hline OPNS & -5.34268 & $(0.0000)^{* * *}$ & -2.46750 & $(0.0068)^{* * *}$ & -2.85678 & $(0.0021)^{* * *}$ & -0.66591 & $(0.2527)$ \\
\hline INF & -3.16512 & $(0.0008)^{* * *}$ & -6.42998 & $(0.0000)^{* * *}$ & -4.43499 & $(0.0000)^{* * *}$ & -5.41192 & $(0.0000)^{* * *}$ \\
\hline GPR & -4.34268 & $(0.0000)^{* * *}$ & -2.72750 & $(0.0058)^{* * *}$ & -2.14678 & $(0.0031)^{* * *}$ & -0.46591 & $(0.2427)$ \\
\hline
\end{tabular}

Source: Authors' results. ${ }^{*}, * *, * * *$ indicates significance level respectively at 0.10 level, at 0.05 level and at 0.01 level.

The results in table 2 show that the non-stationarity hypothesis cannot be rejected when we applied the model with a trend for the OPNS and FDI. This led to applying the unit root test as a first difference. The results are shown in the table below.

Table 2

Test of unitary root in first Difference

\begin{tabular}{|c|c|l|c|c|c|c|c|c|}
\hline \multirow{3}{*}{ Variables } & \multicolumn{4}{|c|}{ LLC (2002) } & \multicolumn{4}{c|}{ IPS (2003) } \\
\cline { 2 - 9 } & model without trend & \multicolumn{2}{|c|}{ model with trend } & model without trend & \multicolumn{2}{c|}{ model with trend } \\
\cline { 2 - 9 } & Statistic & P-values & Statistic & P-values & Statistic & P-values & Statistic & P-values \\
\hline OPNS & - & - & -7.2387 & $(0.0006)^{* * *}$ & - & - & -3.1285 & $(0.0006)^{* * *}$ \\
\hline FDI & - & - & -11.148 & $(0.0006)^{* * *}$ & - & - & -8.6844 & $(0.0006)^{* * *}$ \\
\hline
\end{tabular}

Source: Authors' results. *, **, *** indicates significance level respectively at 0.10 level, at 0.05 level and at 0.01 level.

The results of the tests of LLC (2002), and IPS (2003) applied to the first difference variables show that the hypothesis of non-stationarity is rejected for all variables and therefore all variables are I (1).

\subsection{Presentation of the results}

Once all the coefficients of our model are estimated, the impulse response functions are calculated. The impulse response functions describe the behaviour of one variable following shock on another variable of the system; the shocks on the other variables remain zero. Nevertheless, subsequently the variance-covariance matrix of the errors is infrequently diagonal, it is necessary to decompose the residuals so that they become orthogonal to isolate the shocks of a variable of the system (Love and Zicchino, 2006). This calculation is done through the decomposition of Cholesky. The underlying premise of Cholesky's decomposition is that the variables listed first in the VAR model affect those that do not come as contemporarily as well as those that come later, while those listed at the last affect what is previous only offline. 
The authors applied the Generalized Moment Method (GMM) using the STATA version 12 software to estimate the model Using Arellano - Over (1995) Estimators. The results of the estimation are shown in table 3 .

Table 3

Estimation of PVAR Model

\begin{tabular}{|c|c|c|c|c|c|c|}
\hline Variables & L.hgdp & L.hfdi & L.hinf & L.hopns & L.hindxdf & L.hgpr \\
\hline \multirow{4}{*}{ L.hgdp } & $0.366^{* * *}$ & -0.036 & 0.134 & -0.166 & 0.013 & $-0.174^{*}$ \\
& $(0.121)$ & $(0.071)$ & $(0.203)$ & $(0.242)$ & $(0.014)$ & $(0.068)$ \\
& {$[3.011]$} & {$[-0.514]$} & {$[0.661]$} & {$[-0.686]$} & {$[0.965]$} & {$[-1.715]$} \\
\hline \multirow{3}{*}{ L.hfdi } & 0.219 & $0.517^{*}$ & -0.127 & 0.038 & -0.005 & -0.231 \\
& $(0.151)$ & $(0.288)$ & $(0.419)$ & $(0.254)$ & $(0.025)$ & $(0.622)$ \\
& {$[1.454]$} & {$[1.794]$} & {$[-0.303]$} & {$[0.150]$} & {$[-0.211]$} & {$[-0.37]$} \\
\hline \multirow{3}{*}{ L.hinf } & $-0.134^{*}$ & -0.037 & $0.981^{* * *}$ & 0.194 & 0.002 & 0.083 \\
& $(0.074)$ & $(0.094)$ & $(0.187)$ & $(0.158)$ & $(0.011)$ & $(0.169)$ \\
& {$[-1.815]$} & {$[-0.403]$} & {$[5.232]$} & {$[1.232]$} & {$[0.204]$} & {$[0.494]$} \\
\hline \multirow{3}{*}{ L.hopns } & 0.063 & 0.017 & -0.071 & 0.083 & 0.002 & $0.366^{* * *}$ \\
& $(0.051)$ & $(0.044)$ & $(0.091)$ & $(0.169)$ & $(0.008)$ & $(0.121)$ \\
& {$[1.233]$} & {$[0.388]$} & {$[-0.774]$} & {$[0.494]$} & {$[0.341]$} & {$[3.011]$} \\
\hline \multirow{3}{*}{ L.hindxdf } & 0.713 & 0.488 & -0.378 & -0.231 & $0.311^{*}$ & -0.127 \\
& $(0.472)$ & $(0.595)$ & $(0.800)$ & $(0.622)$ & $(0.092)$ & $(0.419)$ \\
& {$[-1.511]$} & {$[0.820]$} & {$[-0.473]$} & {$[-0.37]$} & {$[3.385]$} & {$[-0.303]$} \\
\hline \multirow{3}{*}{ L.hopr } & $-0.434^{* * *}$ & $-0.174^{*}$ & $-0.181^{*}$ & $-0.194^{*}$ & $-0.144^{*}$ & $-0.134^{*}$ \\
& $(0.073)$ & $(0.068)$ & $(0.074)$ & $(0.074)$ & $(0.068)$ & $(0.074)$ \\
& {$[-3.815]$} & {$[-1.715]$} & {$[-1.832]$} & {$[-1.841]$} & {$[-1.915]$} & {$[-1.815]$} \\
\hline
\end{tabular}

Source: Authors' results. Standard deviations are in parentheses and adjusted heteroscedasticity student statistics are bracketed $*, * *, * * *$ indicates significance level respectively at 0.10 level, at 0.05 level and at 0.01 level.

The results of the previous table (clone 2) show that the growth rate at the first lag is positively and significantly correlated with the $1 \%$ threshold and leads to an rise in the economic growth rate of $0.366 \%$.This result indicates that per capita economic growth is not a black hole, but depends on the growth rates of the previous periods and the implementation of the economic infrastructure, guiding the development of the MENA countries. These results are supported by the theory of sustainable growth based on the conservation of natural resources in more than good governance and adequate income distribution and social security policy. These results are in line with the work of Yilmaz Bayar and Marius Dan Gavriletea (2018) and Zuzana. S, (2014).

On the other hand, the economic growth rate and the GPR index are statistically significant at the $1 \%$ level. In accordance with following studies, the sign of the coefficient of the GPR index turns out to be negative. It was observed that the economic performance of these countries was strongly affected by the geographic risk.

Column (3) presents the determinants of foreign direct investment (fdi). We found that the growth rate of the first delay is not significant, which indicates a causal relationship between economic growth and foreign direct investment. Lagged foreign direct investment (fdi) values are more or less significantly positive, showing that the FDI positively influences economic growth. These results are in line with the work of authors Mohammad A. À and Mahmoud K. A (2014); Lautier and Moreaub (2012), Anwar.S, and Sun. S, (2011) and Kalemli-Ozacan and Sayek (2004). 
Column (4) shows the determinants of inflation; the coefficients associated with this lagged variable are not significant, while one the lagged inflation rate is negative and significant. Indeed, an increase of $1 \%$ in the rate of inflation leads to a decrease of $0.127 \%$ in foreign direct investment. Inflation (INF) is significant and negatively correlated with FDI, which confirms the idea of Romer C. and Romer D. (1998) which assures that inflation has deleterious effects on economic growth through the FDI channel.

Column (5) shows the determinants of commercial opening (h_opns) the coefficients are not significant. This can be due to the application of a trade liberalization policy in an unstable macroeconomic environment, the non-diversification of exports from the MENA region, and the existence of several barriers and obstacles that hinder free trade between these countries and the outside world.

Column (6) shows the determinants of financial development (h_indxdf), not all coefficients, are significant except for the first difference in a positive and significant index. An increase of 1\% (h_indxdf) in the last year has resulted in an increase of $0.311 \%$ in the current (h_indxdf) situation. This leads us to conclude that the quality of financial development is continually improving. These results are similar to the work of Mohammad Amin. Â and Mahmoud Khalid.A. (2014), Okon et al. (2012) and Azman-Saini.S and AbdHalim (2010).

We will refrain from interpreting these results which don't have immense economic explanation. Indeed, the different transformations that have been made on the variables alienate whatever the interpretation that can be made of the model. On the contrary, the overall interest of this model is based on the analysis of the impulse response functions and the decomposition of the variance.

\subsubsection{Impulse response functions}

The simulation of structural shocks is a powerful method in the dynamic analysis of a group of variables. They reflect the reaction over time of variables to identified contemporary shocks. We are going to retrace the responses to the shocks on the residuals of the variables studied over a well-determined period, considered as the time required for them to regain their long-term level and estimate their confidence intervals using Monte Carlo simulations. In practice, new coefficient matrices are generated and the IRFs are recalculated from the variance-covariance matrices. This procedure is repeated several times and, subsequently, the confidence intervals are generated. At the end of the implementation of the IRF, the final step is the decomposition of the variance. This final step shows the percentage of the variation in one variable explained by a shock in another variable, which is accumulated over time. This step is crucial for the current exercise, as it will reveal to what extent the financial development effort of the MENA countries influences their economic growth.

To derive the impulse response functions (IRF), we estimated a VAR model on the stationary variables, in order to corroborate the previously obtained results. The results make it possible to determine the time frame and the magnitude of the shocks on geopolitical tensions, financial development, FDI, as well as their persistence on economic growth. The impulse response functions inform us on the directional evolutions of the variables on the one hand, and on the magnitude of these deviations on the other hand. In figure 2, the response functions that deemed relevant are presented.

A positive financial development index shock generates a very significant positive effect on shortterm economic growth reaching a maximum of $0.11 \%$ in the second year. To then go down during the third year to $-0.7 \%$. Then reach $-0.004 \%$ at the end of the period. It is also observed that there is a negative response at the beginning of the shock of the first year followed by slow growth in the following year until it becomes positive and stabilizes over the rest of the period response to the growth rate of GDP per capita. In other words, the shock is negative in the short term, yet it becomes positive in the 
medium and long term. However, this is accompanied by a low amplitude. FDI's response to a shock on the financial development index produces a positive and instantaneous effect, which peaks in the first year after the shock, and stabilizes in the second year, then declines slightly over the rest of the period. This is a major result of this work as it confirms that financial development has a positive impact on the contribution of FDI to economic growth.

The responses of economic growth have shocks on FDI, inflation, and trade openness. It can be seen that a shock on FDI produces a very strong instantaneous positive effect that peaks in the first year following the shock and decreases over the rest of the period until it becomes negative. The response of the GDP per capita growth rate to a trade opening shock is positive and immediate; peaking in the first year and decreases slightly over the period of the following four years and it stabilizes over the rest of the period. Finally, figure 2 shows that a shock on inflation induces a strong negative instantaneous response to economic growth. Let us now look at the magnitude of the effect of these variables on economic growth.

\subsection{Decomposition of the variance}

Over a given period, the decomposition of the variance makes it possible to know how much variation of the variable in the system is explained by another variable of the latter. To do this, Cholesky decomposition method was used. Based on the variance-covariance matrices of the previously estimated models, this method allows isolating the part of the variance of a given variable of the system. The decomposition of the accumulated variance over a 10-year horizon is presented in the table below.

Table 3

Decomposition of the Variance

\begin{tabular}{|l|c|c|c|c|c|c|c|}
\hline Variables & horizon & Gdp & fdi & opns & inf & Indxdf & GPR \\
\hline Gdp & 10 & 0.5498 & 0.0226 & 0.4090 & 0.0081 & 0.0102 & 0.0416 \\
\hline Fdi & 10 & 0.0476 & 0.8970 & 0.0416 & 0.0012 & 0.0124 & 0.9573 \\
\hline Opns & 10 & 0.0017 & 0.0335 & 0.9573 & 0.0030 & 0.0043 & 0.3632 \\
\hline Inf & 10 & 00123 & 0.0156 & 0.3632 & 0.6070 & 0.0016 & 0.9573 \\
\hline Indxdf & 10 & 0.0210 & 0.0120 & 0.0093 & 0.0015 & 0.9559 & 0.3632 \\
\hline GPR & 10 & 00123 & 0.0156 & 0.3632 & 0.8970 & 0.0416 & 0.0156 \\
\hline
\end{tabular}

Source: Authors' results

Focusing on the contributions of the primary indexes, we note that the variations in economic growth induced by financial development and inflation are minimal, with respectively $1.02 \%$ and $0.80 \%$ over a 10-years period. This result is opposed to the theory which states that financial development is a determinant of economic growth such as Mc Kinnon and Shaw (1973). Therefore financial development must be accompanied by a set of conditions which seem necessary to access the economy macroeconomic financial system to support economic growth.

In other hand, the inflation rate has a negative effect on the growth rate of real GDP. An augmentation in the inflation rate reduces the real GDP growth rate. Inflation hampers the accumulation of monetary assets, which are essential for investment and growth. This encourages governments in the MENA region to ensure a stable economic and political environment.

On the other hand, trade openness and foreign direct investment have a direct effect due to their large variations, which represent respectively $40.90 \%$ and $2.26 \%$, on economic growth over a 10 -year horizon. Indeed, this result implies that the stability of the macroeconomic environment produces important, positive effects on economic growth. 
From what has been discussed, it can be seen that FDI in MENA countries tends to be, for the extraction of raw materials or manufacturing industries, calling for the massive use of a relatively lowskilled and low-paid labor force compared to developed countries. It is also important to note that MENA countries should develop structural reforms to improve the political, economic, and legal climate as well as administrative capacity. This involves simplifying regulations to enhance competitiveness and reduce the attractiveness of the informal economy. Also, it should further promote enterprises and policies for the development of the financial sector through the establishment of a tax framework conducive to investment. They should still enact incentives, improve corporate governance, modernize technical norms, customs standards, and sectorial licensing. Strengthening competition policy, privatization, and protection of intellectual property are also reforms to be undertaken.

In addition, the modernization of the banking system and the development of capital market institutions are conducive to FDI. This builds commercial integrity, combats corruption as well as the informal economy and strengthens countries' national and international networks. Similarly, trade openness indicates that mobilization stimulates savings and better allocation of resources in the economy; this allows for the increase of production and the adoption of more efficient technologies and strengthens specialization, technological innovation, and economic growth. Trade openness supports growth in the region as advocated by endogenous growth theorists.

It should be said, therefore, that even if the macroeconomic components, such as financial development and foreign direct investment, are with leger variation, impulse response functions reveal that the exposure of economic growth to their shocks is more persistent.

\section{CONCLUSION}

In conclusion, the PVAR approach was used to explicitly explain the relationship between the financial development, GPR and economic growth in MENA countries over the period from 1995 to 2020. The regressions are conducted with the Arellano and Bover estimators using the generalized moment method (GMM). In a world where geopolitical tensions between world powers are growing without symmetrical progress in regulatory bodies and procedures, tensions and conflicts have erupted within countries, between countries and at the global level, with an unprecedented scale in reason of the actors, their motives and their procedures. Geopolitical tensions react negatively to the growth of MENA economies. The MENA region is known for constant chaos and wars (for example, in Libya or Syria). Moreover, the aspect of militarism absolutely had a clear effect on economic growth. Furthermore, in MENA region wars and conflicts have been going on for the past 50 years, which almost absolutely denies the possibility of external investment.

This can be explained by an application of a trade liberalization policy in an unstable macroeconomic environment, the non-diversification of exports and the existence of several barriers and obstacles which hinder the free trade between the countries in question and the outside.

Likewise, achieving comprehensive financial reform is not an easy task as it depends on regulatory capacity, legal history, investment culture and cooperation through financial policies. various governments. In the long run, it may be easier for a country to attract more FDI if the development of the financial market is complemented by effective economic policy, including international trade policy.

The results of this empirical study undoubtedly represent a major contribution in understanding the link between geopolitical tensions, financial structure and economic growth. 
Authors contributions: Conceptualization, H.S., M.G and M.B.T.; data curation, H.S. and M.B.T.; writing-review —original draft preparation, H.S. M.B.T M.G and. F.A.; ending, S. T.; supervision, H.S., M.B.T.; project administration, H.S. M.B.T.

Funding: Not applicable.

\section{ACKNOWLEDGEMENT}

The authors would like to express their gratitude to Pr. Samir Maktouf for technical support and encouragement.

Conflicts of Interest: The authors declare that there are no conflicts of interest regarding the publication of this article.

\section{REFERENCES}

Alesina, A., \& Perotti, R. (1996). Political Instability, Income distribution and Investment. European Economic Review, 40, 1203-1228.

Anwar, S., \& Sun, S. (2011). Financial development, foreign investment and economic growth in Malaysia. Journal of Asian Economics, 22(4), 335-342.

Arellano, M., \& Bover, O.(1995). Another look at the instrumental-variable estimation of error-components models. Journal of Econometrics, 68, 29-52.

Arellano, M., \& Bond, S. (1991). Some Tests of Specification for Panel Data. Monte Carlo. Evidence and an Application to Employment Equations. Review of Economic Studies, 58(2), 277-97.

Baltagi, B., H, Demetriades, H., \& Law, H. (2009). Financial development and openness: Evidence from panel data. Journal of Development Economics, 89, 285-296.

Barro, R. (2003). Determinants of economic growth in a panel of countries. Annals of Economics and Finance, 4, 231274.

Beck, T., \& Levine, R. (2004). Stock markets, banks and growth: panel evidence. J. Bank. Finance, 28, 423-442.

Benedictowa, A., \& Roger, H. (2020). A financial accelerator in the business sector of a macro econometric model of a small open economy. Economic Systems, Elsevier, vol. 44(1).

Bode, E., \& Nunnenkamp, P. (2011). Does foreign direct investment promote regional development in developed countries? A Markov chain approach for US states. Review of World Economics, 147(2), 351-383.

Brooks, D., Hasan, R., Lee, J.W, Son, H.H., \& Zhuang, J. (2010).Closing development gaps: challenges and policy options, ADB Economics Working Paper Series. 209.

Caldara, D., Iacoviello, M., \& Markiewitz, A. (2018). Global and country-specific geopolitical risk uncertainty and stock return of fragile emerging economies. Borsa Istanbul Review, 20(3), 197-213.

Chaido, D., \& Emmanouil, S. (2014). Foreign Direct Investments, Exports, and Economic Growth in Croatia: A Time Series Analysis. Procedia Economics and Finance, 14, 181-190.

Choong, C-K., Zulkornain, Y., \& Siew, O .(2004). Foreign direct investment, economic growth, and financial sector development.ASEAN Economic Bulletin, 21, 278-289.

Desbordes, R., \& Shang-Jin, W. (2014). The Effects of Financial Development on Foreign Direct Investment. World Bank Group Policy Research. Working Paper 7065. Washington: World Bank Group.

Durham, J., \& Benson, J.(2004). Absorptive capacity and the effects of foreign direct investment and equity foreign portfolio investment on economic growth. European Economic Review. 48,285-306.

Durusu-Ciftci, D., Ispir, M. S., \& Yetkiner, H. (2017). Financial development and economic growth: Some theory and more evidence. Journal of Policy Modeling, 39(2), 290-306.

Fauzel, S. (2016). Modeling the Relationship between FDI and Financial Development in Small Island Economies: A PVAR Approach. Theoretical Economics Letters. 6,367-75. 
Freytag, A., \& Susanne, F. (2017). Sectoral linkages of financial services as channels of economic development-An input-output analysis of the Nigerian and Kenyan economies. Review of Development Finance. 7(1), 36-44

Gaibulloev, K., \& Sandler, T. (2008).Growth consequences of terrorism in Western Europe.Kyklos, 61(3), 411-424.

Gorg, H., Greenaway, D .(2004). Much ado about nothing? Do domestic firms really benefit from foreign direct investment. World Bank Research Observer. 19, 171-198.

Hausman, J.A. (1978). Specification tests in econometrics. Econometrica, 46, (6), 1251-1271.

Hermes, N., \& Robert, L. (2003). Foreign direct investment, financial development and economic growth. Journal of Development Studies. 40, 142-163.

Mohamed Sghaier, I., \& Zouheir, A. (2013). Foreign direct investment, financial development and economic growth: empirical evidence from North African countries. Journal of International and Global Economic Studies, 6(1), 1-13.

Jung, W.(1986).Financial development and economic growth: international evidence. Economic Development and Cultural Change, 34, 333-346.

King, R.G., \& Levine, R. (1993). Finance and growth: Schumpeter might be right. Quart. J. Econ., 108, 717-738.

Mansour,L., \& Zeaiter, H. (2019).The role geopolitical risks on the Turkish economy opportunity or threat. The North American Journal of Economics and Finance, $50(\mathrm{C})$.

Levin, A., Lin, C. F., \& Chu, C. S. (2002). Unit root tests in panel data: Asymptotic and finite-sample properties. Journal of Econometrics, 108(1), 1-24.

Levine, R., \& Renelt, D. (1992).A sensitivity analysis of cross-country growth regressions. Amerivan Economic Review, 82(4), 942-963.

Mahmoodi, M., \& Mahmoodi, E. (2016). Foreign direct investment, exports and economic growth: Evidence from two panels of developing countries. Economic Research Ekonomska Istrazivanja, 29, 938-49.

Murdoch, J., \& Sandler, T. (2002). Civil wars and economic growth: A regional comparison. Defence and Peace Economics, 13(6), 451-464.

Al Nasser, O.M., \& Xavier, G. G. 2009. Do well-functioning financial systems affect the FDI flows to Latin America? International Research Journal of Finance and Economics. 29: 60-75.

Osei , M.J., \& Jaebeom, K. (2020). Foreign direct investment and economic growth: Is more financial development better? Economic Modelling.154-161.

Ranciere, R., Tornell, A., \& Westermann, F. (2007).Systemic crises and growth. Quarterly Journal of Economics 1, 359-406.

Roubini, N., \&Sala-I-Martin, X. (1992).Financial repression and economic growth. Journal of Development Economics .39, 5-30.

Sahin, S., \& Ilhan, E. (2015). Financial development and FDI in Greece and neighboring countries: A panel data analysis. Procedia Economics and Finance, 24, 583-88

Sala, I., \&Martin, X. (1997). I just ran two million regressions. American Economic Review, 87(2), 178-83.

Samy,N., \& Samir,G. (2007). Stock markets, banks, and economic growth: Empirical evidence from the MENA region" Research in International Business and Finance 297-315.

Solomon, E. (2011). Foreign Direct Investment, Host Country Factors and Economic Growth. Ensayos Revista de Economia, 30(1), 41-70.

Soltani, H., \& Ochi, A. (2012). Foreign Direct Investment (FDI) and Economic Growth: an approach in terms of cointegration for the case of Tunisia. Journal of Applied Finance \& Banking, 2(4), 193-207.

Soltani,H. (2013). Trade openness and economic growth: The case of Tunisia. International Journal of Advances in Management and Economics, 2(2), 24-32.

Soybilgen, B., Kaya, H., \& Dedeoglu, D. (2019). Evaluating the effect of geopolitical risks on the growth rates of emerging countries. Economics Bulletin, 39(1), 717-725.

Triki, M.B., \& Ben Maatoug, A. (2021). The gold market as a safe haven against the stock market uncertainty: evidence from geopolitical risk. Resources Policy, 70, March 2021, 101872.

Yilmaz, B., \& Marius, D. G. (2018). Foreign direct investment inflows and financial development in Central and Eastern European Union countries: A panel cointegration and causality. Int. J. Financial Stud., 6(2), 55.

Zukarnain, Z. (2007). The causality relationship between financial development and foreign direct investment. Journal Kemanusiaan, 10, Disember 2007. 
Okon. K., Osundi. S., \& Dibal. J. (2012). Bacterial contamination of operating theatre and other specialized care unit in a tertiary hospital in Northeastern Nigeria. African Journal of Microbiology Research 6(13):3092-3096

Villegas-Sanchez, C. (2008). FDI spillovers and the role of local financial markets: Evidence from Mexico. European University Institute, Mimeo.

Alesina, A., Sule, O., Nouriel, R., \& Philip, S. (1996). Political instability and economic growth. Journal of Economic Growth, 1(2), 189-211.

Beck, T., E. Feyen, A. Ize et F. Moizeszowic (2008). Benchmarking Financial Development. Policy Research Working Papers no 4638 (Washington, DC : The World Bank). 


\section{ANNEX}

Impulse-responses for 1 lag VAR of gdp fdi inf opns indxdf

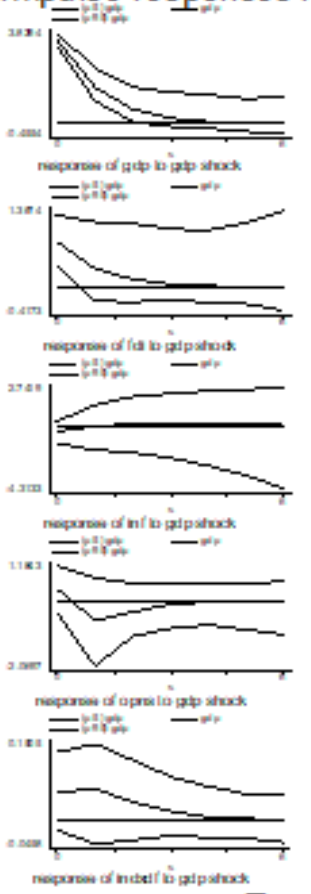

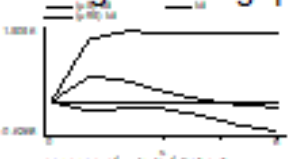

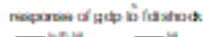
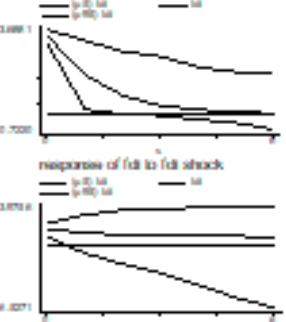

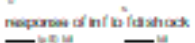

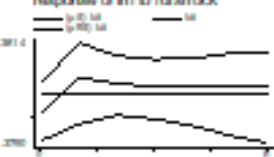

neparioe of upros in is sturs

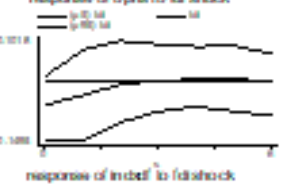

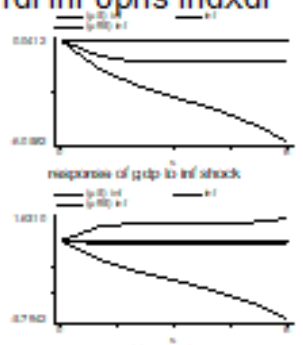
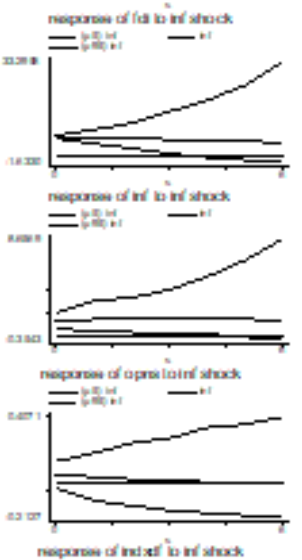

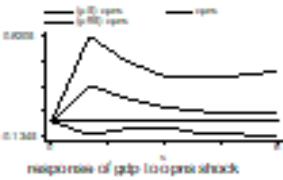

$=+2=-1$

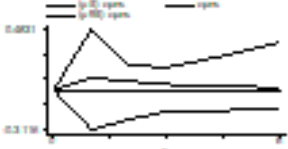

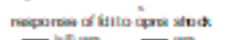
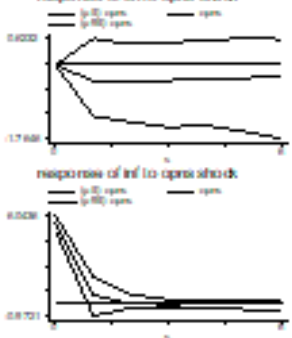

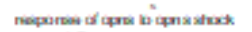

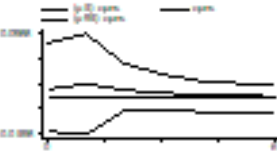

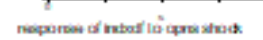

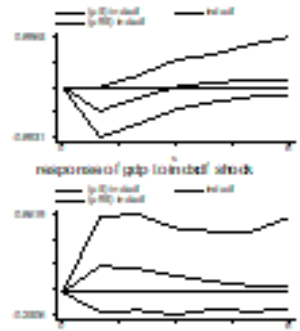

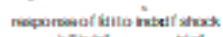

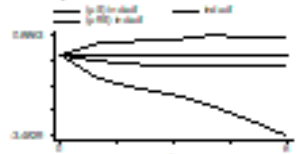

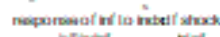

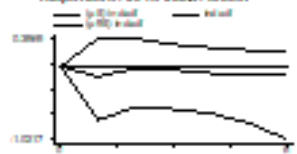

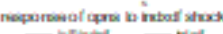

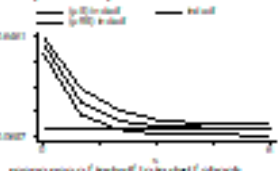

Errors are $5 \%$ on each side generated by Monte-Carlo with 200 reps

Figure 2. Impulse-responses for 1 lag VAR 